\title{
Management of Thoracal and Lumbar Schwannomas Using a Unilateral Approach without Instability: An Analysis of 15 Cases
}

\author{
Suat Canbay ${ }^{1}$, Askin Esen Hasturk ${ }^{1}$, Mehmet Basmaci ${ }^{1}$, Fuat Erten ${ }^{1}$, Ferhat Harman ${ }^{2}$ \\ 1Department of Neurosurgery, Oncology Training and Research Hospital, Ankara, Turkey \\ ${ }^{2}$ Department of Neurosurgery, Near East University Hospital, Mersin, Turkey
}

\begin{abstract}
Study Design: Retrospective case series.
Purpose: The objectives of this study were to determine and discuss the surgical planning of patients who underwent operations following diagnoses of thoracal and lumbar spinal schwannomas. We also aimed to discuss the application of unilateral hemilaminectomy for the microsurgery of schwannomas.
\end{abstract}

Overview of Literature: Schwannomas are located in different regions and sites. These differences require several surgical approaches. Unilateral laminectomy without stabilization of the spine provides a more minimally invasive removal of the tumor

Methods: In this retrospective study, 15 patients with spinal schwannomas were evaluated with regards to age, sex, onset history, neurological findings, tumor locations, McCormick scale, surgical procedure, and operational results. The lateral approach provides exposure of intradural structures and posterior paraspinal regions. Extensions of tumors cause problem for the surgeon in terms of approach, resectability of the tumor, and stability of the spine. Gross total resection was achieved in all cases, and none of the patients necessary required a fusion procedure.

Results: Five patients were males and 10 were females. The age interval was 29-65 years. The tumor was located in the lumbar region in 9 patients, in the thoracic region in 2 patients, and in the thoracolumbar junction in 4 patients. The intradural lesions were removed by laminectomy and the extradural lesions were resected with hemilaminectomy. The paramedian route was used to explore the extraspinal part of the tumor. Costotransversectomy was for the thoracic region. Subtotal resection was performed in 1 patient. Patient symptoms recovered gradually in the postoperative period.

Conclusions: Resection of giant schwannomas is challenging and usually requires a different approach. We describe the complete resection of complex dumbbell or paraspinal schwannomas of the thoracic and lumbar spine by unilateral hemilaminectomy.

Key Words: Thoracolumbar Schwannoma, Unilateral approach, Instability, Management

\section{Introduction}

A total of $40 \%$ of spinal tumors are located in the intradural extramedullary region, $55 \%$ in the extradural, and 5\% in the intradural intramedullary regions. Spinal scwannoma constitutes approximately $25 \%$ of the intradural tumours $[1,2]$ and these arise from Schwann cells. Most of them are benign and show high histological cellularity, whereas multiple forms are generally seen in neurofibromatosis $[3,4]$. They most frequently arise and grow in the posterior and

Received May 13, 2011; Revised Jul 4, 2011; Accepted Jul 14, 2011

Corresponding author: Askin Esen Hasturk, MD

Department of Neurosurgery, Oncology Training and Research Hospital,

Vatan Caddesi, 06200 Demetevler, Ankara, Turkey

Tel: +90-533-728-2904, Fax: +90-312-336-3439, E-mail: aehasturk@yahoo.com

Copyright (C) 2012 by Korean Society of Spine Surgery

This is an Open Access article distributed under the terms of the Creative Commons Attribution Non-Commercial License (http://creativecommons.org/licenses/by-nc/3.0/) which permits unrestricted non-commercial use, distribution, and reproduction in any medium, provided the original work is properly cited. Asian Spine Journal • pISSN 1976-1902 eISSN 1976-7846 
posterolateral sites of the spinal cord on the thoracic region, and are located in the intradural extramedullary region in $50 \%$ of all cases [5-7]. Spinal scwannoma present as dumbbell shaped in $10-15 \%$ of the cases. They are less frequently located in the intramedullary region. The tumors that were totally removed do not show recurrence and the prognosis is good. Also, radiotherapy is often not indicated [8-11]. Fifteen patients with thoracal and lumbar schwannomas were reported. Unilateral hemilaminectomy was used for tumor resection in patients with complex dumbbell or paraspinal schwannomas of the thoracic and lumbar spine.

\section{Materials and Methods}

We documented the data and surgical treatment of $15 \mathrm{pa}-$ tients who were diagnosed with spinal schwannoma, operated, and followed up in our clinic between 2000 and 2010. The age, sex, onset complaints, radiological diagnosis, neurological examination, McCormick Scale [12], surgical techniques, and test results of the patients were evaluated (Table 1). Modified Sridhar classification was used for the location of the tumors (Table 2) [13]. We performed different surgical interventions on our patients according to the tumor location. Intradural extramedullary tumors were
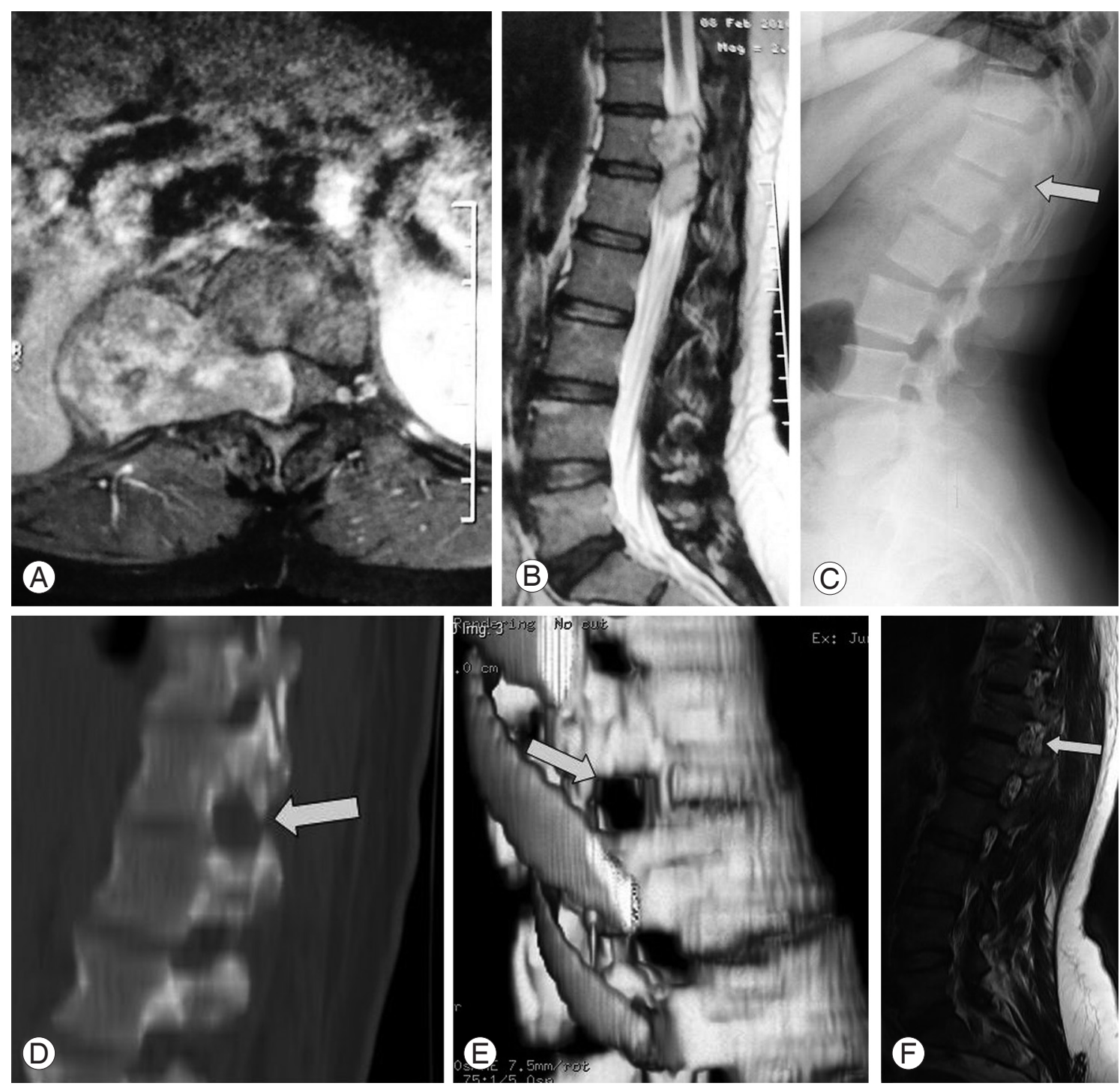

Fig. 1. (A) Axial T1-weighted magnetic resonance imaging (MRI) scan of the patient shows dumbbell tumors which compress the spinal cord. (B) Sagittal T2-weighted MRI scan of the patient shows a dumbbell tumor at the T12-L1 level. Postoperative (C) lateral radiographs of the dorsolumbar spine showing widening of the intervertebral foramina. (D) The ipsilateral neural foraminal widening is observed in computed tomography (CT) (arrow). (E) Three-dimensional CT scan showing enlargement of a vertebral neural foramen (F) T2-weighted sagittal MRI showing widening of the neural foramina. 
dissected from the root under microsurgery and totally removed after the laminectomy and midline dural opening, while the dura was primarily closed. The surgical interventions differentiated for the dumbbell-shaped tumors. Tumors were dissected from the root under microsurgery and totally removed after the laminectomy and midline dural opening ( $\mathrm{T}$ incision if required). The dura defect formed was closed by duraplasty following the removal of the extradural part of the mass. Compatible with this, the related rib was partially excised in the thoracic or thoracolumbar region, while the facet joint was preserved. In that phase, the paravertebral muscles were not lacerated, and may have been hanging to the medial side from the lateral. Having the extraspinal side of the tumor dissected from the soft tissue, the pleura and the bone, and the facet joint without being damaged, was totally excised together with its capsule from the medial to lateral side. It would also be possible to have it excised together with its capsule. As the facet joint is preserved, stabilization was not required (Fig. 1).

In the cases of tumor with extraspinal location, the tumor was located at the foramen and just lateral to the foramen. No compression was available on the dura in the spinal canal and the origin root was explored by hemilaminectomy. This root was incised from its proximal (durable point) by being connected and the tumor capsule was dissected. In that case, the root in the nerve sheath tumor (schwannoma) would always have to be incised (Fig. 2). We initially followed the nerve sheath, explored the tumor together with its capsule, and totally excised the tumor from its rootlets. Later on, we primarily sutured the nerve sheath, but if the tumor is diffusely infiltrated in to the nerve rootlets, this root must totally be excised. Although the root was dissected, no loss of function occurred after surgery. In addition, neurophysiologic monitoring may be used for these levels. The patients were followed up with serial magnetic resonance imaging (MRI) scans.

\section{Results}

Out of all the patients $66 \%$ were females and $34 \%$ were males. The age interval was $29-65$ years. The tumor was located in the lumbar region in 9 patients, the thoracic region in 2 patients, and the thoracolumbar junction in 4 patients. The most frequent complaints included back pain, radiculopathy, myelopathy, motor weakness, and voiding difficulty. The final diagnosis was established by clinical, radiological, and histopathological examination. Direct radiography, computerized tomography (CT), and MRI were used as imaging methods. The onset of the symptoms changed from 1 month to 48 months. The motor functions were evaluated according to the modified McCormick scale: $46 \%$ were grade II, $6 \%$ were grade I, and $46 \%$ were grade III. In neurological examination, motor deficit was detected in $60 \%$ of the patients. Follow-ups from 2 to 48 months showed that the symptoms and signs had significantly improved, and no complication of surgery or spinal abnormality occurred in any of the patients.

\section{Discussion}

Schwannomas are benign tumors that grow slowly and have low invasion and metastasis potential. Spinal schwannoma constitutes approximately $25 \%$ of the intradural spinal tumors [1-12]. Most of them are benign and
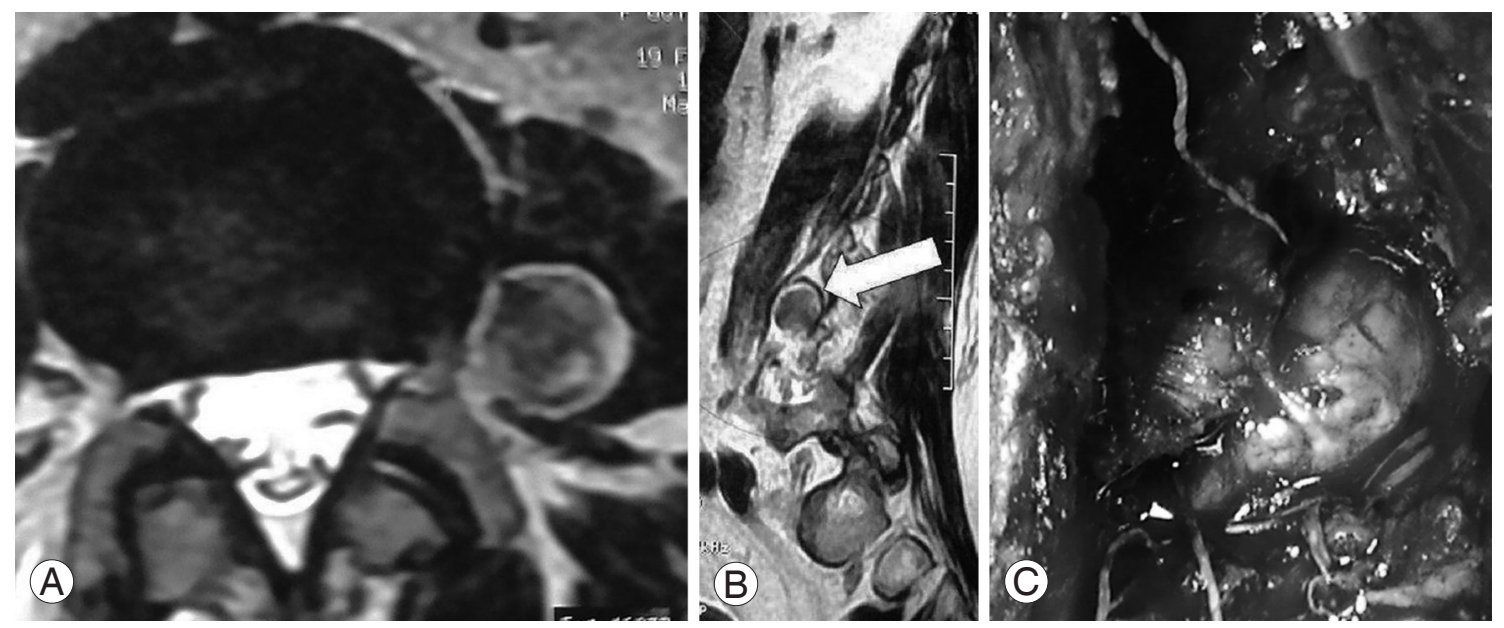

Fig. 2. (A) Axial T2-weighted magnetic resonance imaging (MRI) scan of the patient shows lumbar extraforaminal mass lesion. (B) Sagittal T2-weighted MRI scan of the patient shows the mass lesion, which enlarges the spinal foramina. The arrow shows the tumor. (C) Intraoperative view of the same tumor. 
Table 1. Evaluation of the patients presenting with spinal Schwannoma

\begin{tabular}{|c|c|c|c|c|c|c|c|}
\hline $\begin{array}{l}\text { Age } \\
(\mathrm{yr}) / \\
\text { Sex }\end{array}$ & $\begin{array}{l}\text { Complaints and } \\
\text { duration }\end{array}$ & $\begin{array}{l}\text { Neurologic } \\
\text { examination }\end{array}$ & Location level & $\begin{array}{c}\text { McCormick } \\
\text { Scale }\end{array}$ & $\begin{array}{c}\text { Sridhar } \\
\text { classification }\end{array}$ & Pathology & $\begin{array}{l}\text { Follow- } \\
\text { up } \\
\text { period } \\
\text { (mo) }\end{array}$ \\
\hline 29/M & Back pain, 6 mo & Hypoesthesia & T12-L2 & Grade II & Type 3 & $\begin{array}{l}\text { Schwannom } \\
\text { S-100(+) }\end{array}$ & $2-48$ \\
\hline $32 / \mathrm{M}$ & $\begin{array}{l}\text { Low back - right } \\
\text { leg pain, } 12 \text { mo }\end{array}$ & Radiculopathy & L3 & Grade II & Type 3 & $\begin{array}{l}\text { Schwannom } \\
\text { S-100(+) }\end{array}$ & $2-36$ \\
\hline $37 / \mathrm{M}$ & $\begin{array}{l}\text { Leg pains, } \\
\text { numbness, } 9 \text { mo }\end{array}$ & Motor deficit & L3 & Grade II & Type 2 & $\begin{array}{l}\text { Schwannom } \\
\text { S-100(+) }\end{array}$ & $2-24$ \\
\hline 39/M & $\begin{array}{l}\text { Low back - right } \\
\text { leg pain, } 1.5 \mathrm{yr}\end{array}$ & Paraparesis & L3 & Grade III & Type 3 & $\begin{array}{l}\text { Schwannom } \\
\text { S-100(+) }\end{array}$ & $2-48$ \\
\hline $39 / \mathrm{F}$ & Low back, 5 mo & $\begin{array}{l}\text { Urinary } \\
\text { incontinence }\end{array}$ & T12-L1 & Grade III & Type 4 & $\begin{array}{l}\text { Schwannom } \\
\text { S-100, } \\
\text { vimentin(+) }\end{array}$ & $2-48$ \\
\hline $40 / \mathrm{F}$ & $\begin{array}{l}\text { Numbness in } \\
\text { legs, } 12 \mathrm{mo}\end{array}$ & $\begin{array}{l}\text { No } \\
\text { neurological } \\
\text { deficits }\end{array}$ & $\mathrm{L} 2$ & Grade I & Type 2 & $\begin{array}{l}\text { Schwannom } \\
\text { S-100,CD57(+) }\end{array}$ & $2-12$ \\
\hline $42 / \mathrm{F}$ & $\begin{array}{l}\text { Low back and } \\
\text { leg pain, } 5 \text { mo }\end{array}$ & $\begin{array}{l}\text { T12-L1 } \\
\text { hypoesthesia }\end{array}$ & T12-L1 & Grade III & Type 4 & $\begin{array}{l}\text { Schwannom } \\
\text { S-100, CD57(+) }\end{array}$ & $2-48$ \\
\hline $46 / \mathrm{F}$ & $\begin{array}{l}\text { Walking } \\
\text { difficulty, } \\
\text { numbness in } \\
\text { legs, } 4 \text { mo }\end{array}$ & $\begin{array}{l}\text { Paraparesis } \\
\text { DTR } \\
\text { hyperactive }\end{array}$ & Th12-L2 & Grade III & Type 4 & $\begin{array}{l}\text { Schwannom } \\
\text { S-100, CD57(+) }\end{array}$ & $2-48$ \\
\hline $47 / \mathrm{F}$ & $\begin{array}{l}\text { Pain, numbness } \\
\text { in legs, } 8 \mathrm{mo}\end{array}$ & Paraparesis & T8-9 & Grade II & Type 3 & $\begin{array}{l}\text { Schwannom } \\
\text { S-100, vimentin } \\
(+)\end{array}$ & $2-48$ \\
\hline $51 / \mathrm{F}$ & $\begin{array}{l}\text { Low back and } \\
\text { leg pain, } 12 \text { mo }\end{array}$ & $\begin{array}{l}\text { Radiculopathy, } \\
\text { hypoesthesia }\end{array}$ & L4-L5 & Grade II & Type 3 & $\begin{array}{l}\text { Ancient } \\
\text { Schwannom } \\
\text { S-100(+) }\end{array}$ & $2-48$ \\
\hline $53 / \mathrm{F}$ & $\begin{array}{l}\text { Low back and } \\
\text { leg pain, } 16 \text { mo }\end{array}$ & Hypoesthesia & L3 & Grade II & Type 2 & $\begin{array}{l}\text { Schwannom } \\
\text { S-100(+) }\end{array}$ & $2-24$ \\
\hline $55 / \mathrm{F}$ & $\begin{array}{l}\text { Numbness in } \\
\text { back and right } \\
\text { leg, } 6 \text { mo }\end{array}$ & Paraparesis & Th10-11 & Grade III & Type 4 & $\begin{array}{l}\text { Schwannom } \\
\text { S-100(+) }\end{array}$ & $2-48$ \\
\hline $57 / \mathrm{F}$ & $\begin{array}{l}\text { Low back and } \\
\text { leg pain, } 6-7 \text { mo }\end{array}$ & Paraparesis & $\begin{array}{l}\text { L2-3 } \\
\text { Retroperitoneal }\end{array}$ & Grade III & Type 4 & $\begin{array}{l}\text { Malign } \\
\text { Schwannom } \\
\text { vimentin, } \\
\text { S-100(+) }\end{array}$ & $2-48$ \\
\hline $60 / \mathrm{F}$ & $\begin{array}{l}\text { Low back and } \\
\text { leg pain, } 9 \text { mo }\end{array}$ & Paraparesis & L3-4 & Grade II & Type 3 & $\begin{array}{l}\text { Schwannom } \\
\text { S-100(+) }\end{array}$ & $2-48$ \\
\hline $65 / \mathrm{M}$ & $\begin{array}{l}\text { Low back and } \\
\text { leg pain, } 14 \text { mo }\end{array}$ & Paraparesis & L1-2 & Grade III & Type 3 & $\begin{array}{l}\text { Schwannom } \\
\text { S-100(+) }\end{array}$ & $2-48$ \\
\hline
\end{tabular}

present high histological cellularity, and are shaped like solid masses forming up of Antoni A and Antoni B type cells [2-8]. Multiple forms are generally seen in the case of neurofibromatosis $[3,4]$. These tumors grow slowly, but malign transformation can occur, and have been seen in the 4th and 5th decades [5]. Although Conti et al. [7] reported 
Table 2. Modified Sridhar classification of benign nerve sheath tumors (From Park SC et al. J Korean Neurosurg Soc 2009;46:403-8, with permission from the Korean Neurosurgical Society) [22]
Original types
Type I Intraspinal tumor $<2$ vertebral segments in length; a: intradural; b: extradural
Type II Intraspinal tumor $>2$ vertebral segments in length (giant tumor)
Type III Intraspinal tumor with extension into nerve root foramen
Type IV
Intraspinal tumor with extraspinal extension (dumbbell tumors); a: extraspinal component $<2.5 \mathrm{~cm}$; $\mathrm{b}$ : extraspinal component $>2.5 \mathrm{~cm}$ (giant tumor)
$\begin{array}{ll}\text { Type } \mathrm{V} & \text { Tumor with erosion } \\ \text { myofascial planes }\end{array}$

Additional types for spinal intraosseous schwannoma

Type VI Tumor in entirely intravertebral location without intraspinal portion $\begin{array}{ll}\text { Type VII } & \text { Intraspinal tumor with erosion into vertebral bodies (invasive tumor) and extension into nerve root } \\ \text { foramen }\end{array}$

that it was more frequently seen in males, McCormick et al. [12] reported that this rate was equal in both sexes. The age of our patients changed between the 3rd and 6th decades, and female prevalence was obvious. The tumor was most frequently located at the thoracic, cervical, and lumbar regions, respectively [5]. McCormick et al. [12] reported that this location order covered all tumors of the intradural extramedullary regions. Our patients were presented with lumbar and thoracic involvement. The most frequent location in our series was the lumbar region. The first symptoms included low back pain and radicular pain. It was reported that the pain increases at night and in the late period of the tumor, spinal cord findings occur as well [1-5]. Other signs of spinal schwannoma included motor weakness, sphincter problems, and sensorial disorders. The final diagnosis should be established by clinical findings and imaging methods and MRI is the best method for diagnosis and differential diagnosis [1-7]. The size and specific margins of the mass demonstrate the localization and invasion to the contiguous structures. The changes such as foramen enlargement and erosion in the pedicles detected in the direct graphs may be seen as masses with sharp margins and involve the peripheral contrast in the CT scans $[14,15]$. Schwannomas are frequently located in the extramedullary region, and may present as dumbbell shaped in $10-15 \%$ of cases. They may also be located at the intramedullary region. Ten percent of the tumors were in the extradural location, and $1 \%$ in the intradural intramedullary regional location [5-12,14-17]. Our patients most frequently presented with intradural ex- tramedullary location. The mean complaint period may be 4-6 weeks to 2 years and more [7-12,14,18], and changed from 1 month to 2 years in our patients. We can speculate that early diagnosis was established in many patients. When the long-term results were investigated in the literature, the healing and mortalities of the schwannomas that were located in the lumbosacral region were better [6-10].

Clinical patterns of the patients were generally stable and the transformation rates were relatively low. Considering the locations of the schwannomas in our patients, we observed that the early period and late period surgical results were better when compared with the results of the preoperative examinations. The early diagnosis and appropriate surgical intervention resulted in good clinical outcome [2-10]. None of our patients presented with clinical deterioration and none of them died. Generally, approach to intradural spinal pathology was via total laminectomy. Total laminectomy may cause spinal instability and kyphosis due to damage to the musculoligamentous structures and posterior bony elements. Fusion may be required to correct postlaminectomy deformity and stabilize the spine. Although laminoplasty decreased spinal instability and deformity, it did not stop it. After the use of an operation microscope, intradural neoplasms can be safely and effectively treated with hemilaminectomy techniques. The classical posterior approach may be adopted in the surgery and the modified posterior approaches may, in particular, be used in the large invasive or dumbbell-shaped tumors [11,12,14-19]. In the classical posterior approach, the tumor is reached by dural incision 
through the median incision by multilevel laminectomy [712,14-20]. This may sometimes lead to instability due to muscle ligament dissection.

Regarding the location and size of the tumor, the major objectives of surgery are to perform decompression without instability and remove the tumor by not damaging the neural tissue $[21,22]$. Some surgeons excise the tumor by lateral hemilaminectomy for this reason. It is only possible to perform total resection with additional costotransversectomy in case of the dumbbell-shaped schwannomas demonstrating paraspinal extension $[11,12,14-18,20]$. The surgical approach and the numbers of bone window to be opened are associated with the tumor location and the size of the extradural component [7-11,13]. Despite being benign tumors, spinal schwannomas may show recurrence after subtotal removal. Park et al. [13] supported a new classification system for spinal schwannomas to solve this problem and suggested 2 types of giant spinal schwannomas, dumbbelltype intraspinal tumors with extraspinal extension $>2.5 \mathrm{~cm}$, and invasive tumors with erosion of the vertebral bodies and lateral and posterior extensions into myofascial planes. Park et al. [13] examined the spinal schwannomas under 5 types (Table 2). Most of our patients were in the type 3 and type 4.

Schwannomas are located in different regions and sites. These differences require several surgical approaches. Spinal instrumentation is rarely needed for these tumors because the disc capsule and ligaments remain intact even if the pedicle and posterior elements are compromised.

\section{Conclusions}

We presented a group of 15 patients with spinal schwannoma. These are the most frequent tumors in the spinal cord. Early prognosis is established before the onset of severe neurological symptoms, and total resection positively affects the results. The tumor location is one of the most substantial parameters that affect the clinical outcome. It is possible to perform total resection considering the tumor location by not causing instability. Unilateral laminectomy without stabilization of the spine provides a more minimally invasive removal of the tumor, reducing blood loss and shortening the duration of hospital stay, and is a good alternative surgical approach.

\section{REFERENCES}

1. Engelhard HH, Villano JL, Porter KR, et al. Clinical presentation, histology, and treatment in 430 patients with primary tumors of the spinal cord, spinal meninges, or cauda equina. J Neurosurg Spine 2010;13:67-77.

2. Safavi-Abbasi S, Senoglu M, Theodore N, et al. Microsurgical management of spinal schwannomas: evaluation of 128 cases. J Neurosurg Spine 2008;9:40-7.

3. Holland K, Kaye AH. Spinal tumors in neurofibromatosis-2: management considerations - a review. J Clin Neurosci 2009;16:169-77.

4. Klekamp J, Samii M. Surgery of spinal nerve sheath tumors with special reference to neurofibromatosis. Neurosurgery 1998;42:279-89.

5. Celli P, Trillò G, Ferrante L. Spinal extradural schwannoma. J Neurosurg Spine 2005;2:447-56.

6. Jankowski R, Szmeja J, Nowak S, Sokół B, Blok T. Giant schwannoma of the lumbar spine: a case report. Neurol Neurochir Pol 2010;44:91-5.

7. Conti P, Pansini G, Mouchaty H, Capuano C, Conti R. Spinal neurinomas: retrospective analysis and longterm outcome of 179 consecutively operated cases and review of the literature. Surg Neurol 2004;61:34-43.

8. Seppälä MT, Haltia MJ, Sankila RJ, Jääskeläinen JE, Heiskanen O. Long-term outcome after removal of spinal schwannoma: a clinicopathological study of 187 cases. J Neurosurg 1995;83:621-6.

9. De Verdelhan O, Haegelen C, Carsin-Nicol B, et al. MR imaging features of spinal schwannomas and meningiomas. J Neuroradiol 2005;32:42-9.

10. Ahn DK, Park HS, Choi DJ, Kim KS, Kim TW, Park SY. The surgical treatment for spinal intradural extramedullary tumors. Clin Orthop Surg 2009;1:16572.

11. Sim JE, Noh SJ, Song YJ, Kim HD. Removal of intradural-extramedullary spinal cord tumors with unilateral limited laminectomy. J Korean Neurosurg Soc 2008;43:232-6.

12. McCormick PC, Post KD, Stein BM. Intradural extramedullary tumors in adults. Neurosurg Clin N Am 1990;1:591-608.

13. Park SC, Chung SK, Choe G, Kim HJ. Spinal intraosseous schwannoma: a case report and review. J Korean Neurosurg Soc 2009;46:403-8.

14. Barnowsky L, Dalal R. Extradural schwannoma 
manifested as an expansile vertebral lesion. AJR Am J Roentgenol 1992;159:1352-3.

15. Van Goethem JW, van den Hauwe L, Ozsarlak O, De Schepper AM, Parizel PM. Spinal tumors. Eur J Radiol 2004;50:159-76.

16. Kono K, Inoue Y, Nakamura H, Shakudo M, Nakayama K. MR imaging of a case of a dumbbellshaped spinal schwannoma with intramedullary and intradural-extramedullary components. Neuroradiology 2001;43:864-7.

17. Nakamura H, Komagata M, Nishiyama M, Taguchi M, Kawasaki N. Resection of a dumbbell-shaped thoracic neurinoma by hemilaminectomy: a case report. Ann Thorac Cardiovasc Surg 2007;13:36-9.

18. Huang JH, Simon SL, Nagpal S, Nelson PT, Zager EL. Management of patients with schwannomatosis: report of six cases and review of the literature. Surg Neurol
2004;62:353-61.

19. Agrawal A, Srivastava S, Joharapurkar SR, Gharde P, Ubeja G. Single stage complete excision of large thoracic dumbbell schwannoma by modified posterior approach. Surg Neurol 2008;70:432-6.

20. Hasegawa M, Fujisawa H, Hayashi Y, Tachibana O, Kida S, Yamashita J. Surgical pathology of spinal schwannomas: a light and electron microscopic analysis of tumor capsules. Neurosurgery 2001;49:1388-92.

21. Agrawal A, Cincu R, Wani B. Modified posterior unilateral laminectomy for a complex dumbbell schwannoma of the thoracolumbar junction. Acta Orthop Traumatol Turc 2009;43:535-9.

22. Choudry Q, Younis F, Smith RB. Intraosseous schwannoma of D12 thoracic vertebra: diagnosis and surgical management with 5-year follow-up. Eur Spine J 2007;16 Suppl 3:283-6. 